\title{
Achievement Goals of Youngsters in Rio de Janeiro in Different Contexts ${ }^{1}$
}

\author{
Dandara de Oliveira Ramos² \\ Maria Lucia Seidl-de-Moura \\ Luciana Fontes Pessôa \\ Universidade do Estado do Rio de Janeiro, Rio de Janeiro-RJ, Brazil
}

\begin{abstract}
In this study, we compared the Future Goals of 160 youngsters (16-30 years-old; 71 female and 89 male). University students and slum-dwelling youth were compared. Participants completed a sociodemographic questionnaire, information about their families and two open questions: "What do you expect to do in your life that you consider very important?" and "Do you believe you'll achieve that? Why?" Predicted differences in the participants' answers between the two groups were observed. Favela youth showed higher levels of uncertainty while describing their goals and also presented lower scores of objectives. From an Evolutionary perspective of Psychology, through the Life Story Strategies Theory, we concluded that, for young people from different social contexts, the ways of planning the future tend to vary depending on the adaptability of achievement due to the present constraints in the youth's realities.
\end{abstract}

Keywords: young adults, achievement, future discounting, evolutionary psychology

\section{Metas de Realização de Jovens do Rio de Janeiro em Contextos Distintos}

Resumo: Este estudo teve por objetivo comparar as metas de realização de jovens de dois contextos distintos: universitários e moradores de favela. Participaram 160 jovens do Rio de Janeiro: estudantes universitários $(n=80)$ e jovens moradores de duas favelas cariocas (Rocinha, $n=40$ e Vigário Geral, $n=40$ ), de ambos os sexos, com idades entre 16 e 30 anos. Os participantes responderam ao questionário sociodemográfico, questões referentes à família e duas perguntas abertas: "O que você pretende realizar em sua vida que considera muito importante?" e "Você acredita que conseguirá realizar isso? Por quê?". Por meio da análise de conteúdo temático-categorial observou-se uma diferença significativa entre os grupos no número de metas relatadas, esperança de realizá-las e justificativas referentes à esperança de realização. A partir da Teoria Evolucionista das Estratégias de História de Vida, conclui-se que para jovens de diferentes contextos os modos de planejar o futuro tendem a variar em função das limitações e possibilidades presentes.

Palavras-chave: jovens, realização, desconto futuro, psicologia evolucionista

\section{Los Objetivos Futuros de Jóvenes en Rio de Janeiro en Diferentes Contextos}

\begin{abstract}
Resumen: La finalidad en este estudio fue comparar las metas de rendimiento de jóvenes de dos contextos distintos: estudiantes universitarios y jóvenes que viven en barrios pobres. Participaron 160 jóvenes de Rio de Janeiro: estudiantes universitarios $(n=80)$ y jóvenes que viven en dos barrios pobres (Rocinha, $n=40$ y Vigário Geral, $n=40$ ), ambos sexos, entre 16 y 30 años de edad. Los participantes respondieron un cuestionario sociodemográfico, cuestiones relacionadas con la familia y dos preguntas abiertas: “¿Qué es lo que quiere lograr en su vida que considera muy importante?” y “ ¿Usted cree que puede lograr esto? ¿Por qué?”. Aplicando el análisis de contenido temático-categorial, se identificó una diferencia significativa entre los grupos en el número de objetivos reportados, en la esperanza de alcanzarlos y en las justificaciones relativas a esta esperanza. Con base en la Teoría de la Evolución de las Estrategias de Historia de Vida, se concluye que, para los jóvenes en contextos diferentes, las maneras de planificar el futuro varían de acuerdo a las posibilidades y limitaciones actuales.
\end{abstract}

Palabras clave: jóvenes, realización, descuento del futuro, psicología evolucionista

In this paper, we depart from an evolutionary perspective of Psychology, through the life story strategies theory (Del Giudice \& Belsky, 2011), to investigate the accomplishment goals of youngsters in different contexts in the State of Rio de Janeiro: slum dwellers (Rocinha and Vigário Geral) and college students who do not live in slums.

Various studies have been developed about the theme of youngsters' accomplishment goals and their future projects.

\footnotetext{
${ }^{1}$ Support: National Council for Scientific and Technological Development (CNPq).

2 Correspondence address:

Dandara de Oliveira Ramos. Rua São Francisco Xavier, 524, $10^{\circ}$ andar, Sala 10.004F, Maracanã. CEP 20550-013. Rio de Janeiro-RJ, Brazil.

E-mail: dandararamos2@gmail.com
}

The priority focus areas are: (a) the combination of specific neural and cognitive processes (D'Argembeau et al., 2010; Ersner-Hershfield, Garton, Ballard, Samanez-Larkin, \& Knutson, 2009; Ersner-Hershfield, Wimmer, \& Knutson, 2009; Natanzon \& Ferguson, 2012; Schacter \& Addis, 2009); (b) intrinsic motivational aspects (Carvalho, Pocinho, \& Silva, 2010; Jang \& Liu, 2012; Lee, McInerney, Liem, \& Ortiga, 2010; Peetsma \& van der Veen, 2011); (c) variables of the youngsters' proximal relations, with the family, school, teachers and the circle of friends (Black \& Deci, 2000; Deci, Koestner, \& Ryan, 2001; Deci, Vallerand, Pelletier, \& Ryan, 1991; Filak \& Sheldon, 2003; Garn, Matthews, \& Jolly, 2010; Hill, Jenkins, \& Farmer, 2008; Ryan \& Deci, 2000; Ryan \& Niemiec, 2009; Ryan, Stiller, \& Lynch, 1994; Ryan 
\& Weinstein, 2009; Tabachnick, Miller, \& Relyea, 2008; Wang, 2008); and (d) the influence of psychopathologies like depression and anxiety disorders on the construction of future goals for the young subjects (Bell \& Jenkins, 1993; Damon, 1995; Lorion \& Saltzman, 1993; Osofsky, Wewers, Hann, \& Fick, 1993).

We believe in the importance of these factors and processes to study the theme but, like Garbarino (2008), we defend that, to investigate any human phenomenon, the simple cause-and-effect relations need to be questioned in order to understand the wide range of social (context, culture, risk, economic conditions, resources, among others), psychological (temperament, personality, cognition, notion of self, among others) and biological (brain functioning, genetic propensities deriving from the evolution of the species) variables involved in the elaboration process of a subject's goals.

According to a study disseminated by the Special Secretary of Human Rights in partnership with the Study Group on Violence, affiliated with the Universidade do Estado do Rio de Janeiro, it is estimated that, in six years, violence can kill about 33 thousand youngsters in Brazil. In addition, on the list of 267 cities in the study, Rio de Janeiro ranks $21^{\text {st }}$ (BBC, 2009). Hence, the question is raised how this scenario of social violence affects the future perspectives of young subjects.

Leccardi (2005) discusses the relation between these two processes, indicating the influence of social risk and its different epidemiological extensions today and how this relates to the ways of understanding the future for young people and for society as a whole. As we know from daily experience and based on the data mentioned, our post-modern experience is characterized by a dimension of different risks. According to Rosa (2003), this scenario marked by risk influences people's behavior, especially in case of young people. The author indicates that social pressures are intrinsically related with how we tend to plan our lives and build future projects. As for young people, in this environment surrounded by distinct threats, the meaning itself of juvenile identity changes. Over a lengthy time horizon, the people who experience it tend to appreciate it more because of what it can offer here and now than because of what it makes possible to construct for the future, as this is unavailable and, in a way, threatened.

The relation between the development of future goals and youngsters' behaviors in different contexts has been observed in some studies. Günther and Günther (1998) investigated the influence of socioeconomic variables (such as age, gender, school year, work, school they attend) on the future aspirations of youngsters from poor and rich areas of Brasília. They proposed that, for the study sample, this class difference distinguishes between different perceptions on the opportunities they expect to have in life: attending a public school was associated with not expecting to have one's own house or a good job, while attending a private school was associated with better future professional expectations. Oliveira, Pinto and Souza (2003) investigated the future perspectives of adolescents from different social groups in the same city. Their results demonstrated that, at the time of the research, the levels of concern with the college and professional career were similar and that, independent of gender and institutional context, their perspectives regarding continuing education were more positive than regarding their transition to the job world. These results differ from Günther and Günther (1998).

Oliveira and Saldanha (2010) also found different results. When comparing future perspectives of students from public and private schools in João Pessoa (PB), they observed that the youngsters in both groups had similar expectations about the future, positive perspectives about having a good job, their own house and getting into college, and only differed in the ranking of the most frequent categories. The authors suggest that the different results between the two studies are due to the better opportunities available for young people since 1998, when the research by Günther and Günther was carried out. It is believed that the social mobility young Brazilians expect positively affected the expectations as declared in the more recent research. Although they took into account the social differences between the groups under analysis, the studies reported in this research depart from a theoretical framework that hardly explores the role of the context in development, sometimes limiting the explanation to motivational and cognitive processes: the Theory of the Future Time Perspective, by Nuttin (1983) and Lens (1993). Developed at the University of Leuven, Belgium, this theory privileges the motivational sphere and the temporality dimension involved in human behaviors. The future time perspective is then considered as a stable personality aspect, which will depend on individuals' motivation and engagement in their projects (Schmitt, 2010). It is important, however, to question whether motivation and engagement are truly the sole variables involved in the process.

To investigate the goals of youngsters in adverse realities (BBC, 2009), it is important to investigate the possible psychological consequences of these issues, based on a sensitive theoretical framework. Therefore, in this study, we depart from Evolutionary Psychology, using the Life Story Strategies Theory by Del Giudice and Belsky (2011).

\section{Evolutionary Theory of Life Story Strategies}

Evolutionary Psychology (EP) aims to explain the functioning of our adapted mind, as a product of natural selection, in the evolutionary adaptation context (Barkow, Cosmides, \& Tooby, 1992). The evolutionary approach of Psychology, in its distinguished explanation mode, presents some premises to understand human behaviors towards the future, particularly for young subjects. Planning and investing in the future are conducts related to a range of factors: (a) having an ancestral history to be taken into account; (b) based on this ancestral history, specific mechanisms were molded in our brain functioning which privilege the presente instead of the future; (c) the development of the individual in the ontogenesis does not repeat the philogenesis, but is directed at certain variables related to reproductive success, survival and adaptation. 
Thus, EP proposes that we tend to use the most adaptable strategies in function of the different developmental contexts we are presented with. For contexts of poverty and vulnerability, for example, it is more advantageous to suppress long-term planning and invest in short and medium-term survival and reproduction (Williams, 1957). Based on this interaction between the context demands and the characteristics of the human mind, the subjects develop different life story strategies which, according to Del Giudice and Belsky (2011), consist in identifying the solutions that are best adapted to the different challenges present in the environment. These challenges and variations in the socioecological environment (mainly risks, economic scarcity/abundance and mortality rates) provide the clues needed to allow us to strategically respond to these challenges, accessing the mechanisms that genetically involved in our minds to establish future goals compatible with different social developmental conditions. These different conditions end up allowing individuals to adopt two possible strategic styles to organize their vital effort: a fast strategy (fast LH) - maturing and early reproduction, engagement in more risky activities and short to medium-term future perspectives; or slow/extended strategies (slow LH) - the opposite pattern.

The innovation offered by Evolutionary Psychology, in this study represented by the Life Story Strategies Theory (Del Giudice \& Belsky, 2011), is that it includes sociodemographic variables as contextual factors that are very important to human development, and also that it explains the adaptive value of the different strategies to deal with a wide range of living conditions. In that context, this study intends to contribute by studying the future goals of two groups of youngsters: slum dwellers from two slums in Rio de Janeiro and college students who do not live in slums. Although the issue is not new, no earlier research of young slum dwellers was identified, nor any study based on evolutionary hypotheses.

Departing from the evolutionary theoretical framework, two hypotheses are adopted: (1) That the young slum dwellers will show more uncertainty towards their future objectives, as well as a smaller number of accomplishment goals; (2) That the young slum dwellers will present different categories of future targets, given the influence of the study variables. Hence, the goal in this study was to compare the accomplishment goals of youngsters in two distinct contexts: college students and slum dwellers.

\section{Method}

In this study, data are used from the project: "Future discounting: A study of young people in Rio de Janeiro", developed by the research group Social Interaction and Development (Ramos \& Victor, 2009). Only part of the questions from the original questionnaire was used for the analyses.

\section{Participants}

The study participants were 160 young people, between 16 and 30 years of age, male and female: 40 dwellers (19 men,
21 women) of the slum Rocinha (HDI $=0.073), 40$ dwellers (20 men, 20 women) of the slum Vigário Geral (HDI $=0.076$ ) and 80 college students ( 32 men, 48 women) who lived in middle-class neighborhoods with a higher HDI than in the slums $(M=0.082, S D=0.05)$. The mean HDI of the college student group ranks $18^{\text {th }}$ on a list of 126 neighborhoods, while Vigário Geral ranks $107^{\text {th }}$ and Rocinha $120^{\text {th }}$ (Brazilian Institute of Geography and Statistics, 2008). Table 1 displays the participants' sociodemographic characteristics.

Table 1

Sociodemographic Characteristics of the Participants

\begin{tabular}{lcccc}
\hline Variables & $\begin{array}{c}\text { College } \\
\text { Students }\end{array}$ & $\%$ & $\begin{array}{c}\text { Slum } \\
\text { Dwellers }\end{array}$ & $\%$ \\
\hline Age & & & & \\
$16-20$ & 42 & 52.5 & 43 & 53.8 \\
$21-25$ & 29 & 36.3 & 23 & 28.9 \\
$26-30$ & 9 & 11.2 & 14 & 17.7 \\
Gender & & & & \\
Male & 32 & 40 & 39 & 48.8 \\
Female & 48 & 60 & 41 & 51.3 \\
Monthly Family Income & & & & \\
No Income & 0 & 0 & 1 & 1.3 \\
R\$ 101 - R \$ 500 & 3 & 8.9 & 22 & 28.8 \\
R\$ 500 - R \$ 1000 & 15 & 18.9 & 33 & 41.3 \\
R\$ 1001 - R \$ 2000 & 24 & 30 & 17 & 21.3 \\
R\$ 2001 - R \$ 4000 & 26 & 32.5 & 6 & 7.6 \\
More than R\$ 4000 & 7 & 8.8 & 0 & 0 \\
\hline
\end{tabular}

A significant association was found between the monthly income category and the participant's group $\left(x^{2} 3=41.94, p<.05\right)$. Most families of the slum dwellers (56\%) show monthly income levels inferior to 1000 reais, while $57 \%$ of the college students declared a monthly family income superior to 2000 reais. This indicates a different reality from the economic viewpoint. In general, more people live at the interviewees' homes in the slum communities $(M=4.1 ; S D=1.8)$ than in the college students' families $(M=3.14 ; S D=1.13)$. The result of the GLM analysis was significant: $F(1.158)=14.61 ; p<.05$; power $=.93)$. Most slum dwellers work $(63.75 \%)$, but $41.25 \%$ of the college students also do so, which may reflect the current reality of young people in Rio de Janeiro. The group is associated with the contribution to family income $\left(x^{2} 1=5.05, p<.05\right)$. Only $32 \%$ of the college students report this contribution, against $50 \%$ of the youngsters living in the slums.

\section{Instruments}

The participants answered a sociodemographic data (monthly family income, age, gender, position in the birth order among siblings, place of resident of the participant) survey with open and closed questions and two questions on their self-reported expectations and accomplishment targets. The questions were as follows: What do you intend 
to do in your life which you consider very important? (Accomplishment goals) and Do you think you will be able to do that? Why? (Hope of Accomplishment and Justification).

\section{Procedure}

Data collection. The young college students came from eight different educational institutions (three public and five private) and all of them were taking the first three course semesters. The participants were interviewed during visits to the two slums and eight colleges, where they were invited to answer the questionnaire after signing the Informed Consent Form. At the colleges, the faculty members helped with data collection, which took place in the classroom; in the communities, the researchers visited the participants' homes and other convenient places (schools, college admission courses, among others). The interviewers were familiar with both communities' context.

Data analysis. To characterize the sample, Uni and Multivariate analyses were used in SPSS (Statistical Package for Social Sciences) version 19.0. To test for differences between the two groups' goal accomplishment scores, a $t$ test for independent groups was applied. The treatment chosen for the data collected through the open questions was thematiccategorical content analysis (Oliveira, 2008) and the following categories were identified:

The answers to the question "What do you consider doing in your life which you consider very important?", the answers were entitled Accomplishment Goals and organized in the following categories: (a) Professional goals - which comprise answers involving desires related to the interviewee's professional life, such as a salary raise, a promotion, among other answers with similar contents; (b) Academic goals - which comprise answers involving desires related to the interviewee's academic background, like the conclusion of a program, better grades and a better school performance, admission to a college, approval on the admission test, among other answers with similar contents; (c) Material purchases answers about the purchase of some specific good, like a house, a car, a motorcycle, among others; (d) Goals with emotional content - answers related to expected moods and expressions like: "achieve peace" or "be happy", for example; (e) Family goals - which comprise answers about the participant's family life, goals related to child raising, marriage, relation with parents, among other answers with similar contents; (f) Social (help) - answers that express the desire to help other people (not necessarily relatives), enhancing their wellbeing and safety; (g) Social (relations and knowledge) - which comprise the respondent's desire to expand their relationship networks, get to know new people, places and social situations; (h) Selfaccomplishment - answers that express the respondent's desire for self-accomplishment, without reporting on any specific targets. The answers to the question: "Do you think you will be able to do this? Why?", were entitled Hope of Accomplishment - "yes", "no" or "I don't know" for the first question - and Justification of Hope of Accomplishment for the second.
In the analysis of the justifications, some categories were also adopted for the sake of standardization: (a) Circumstantial justifications - relate to circumstances or specific events in the participant's life (change of residence, particular problem(s) he is facing, among others); (b) Motivational justifications - expressions like: "I really want that", "I'm going to fight really hard for that to happen", "I am very strong-willed", for example; (c) The concrete effort the participant is already making to achieve that objective - cases in which the participant is already doing some effective action to conquer his/her goals, when (s)he is already studying, saving money, getting training or other kinds of attitudes related to the achievement of his/her objectives.

\section{Ethical Considerations}

The project Future discounting: A study of young people in Rio de Janeiro received approval from the Research Ethics Committee at UERJ-COEP/UERJ (Opinion 036/2008).

\section{Results and Discussion}

\section{Accomplishment Goals}

The answers to the first question, "What do you consider doing in your life which you consider very important?", were transcribed and registered in databases. Different types of analysis were used. To assess the difference between the number of goals the participants informed, the $t$ test for independent groups and the univariate GLM for gender differences were used. The goals mentioned in their description were interpreted through thematic-categorial content analysis. Then, the categories were registered in the form of a database in SPSS for Windows and analyzed in descriptive procedures (frequencies, data distribution) and tests of intergroup association (chi-squared). Next, the results for each kind of data analysis are described separately:

\section{Goal Score}

As regards the total number of goals the participants mentioned, no gender differences were identified. Both the interplay between gender and group: $F(1.165)=24.61$; $p>.05$; power $=.07)$ and the separate observation of the gender variable: $F(1.740)=16.83 ; p>.05$; power $=.15$ ), showed similar means between male and female participants. These results should be interpreted with caution though, due to the low power coefficients.

On the opposite, when comparing the groups, it was observed that the goal score $(M=2.9 ; S D=1.07)$ was higher for the college students than for the young slum dwellers $(M=1.2 ; S D=1.06)$ and that this difference was statistically significant $(t(121)=-2.37 ; p=.02)$. The GLM result did not indicate any significant difference in the goal score when observing the interaction with the variables birth order, income groups or age ranges. 


\section{Goal Categories}

The goals indicated in the answers were analyzed in the order in which the participants described them. A significant difference was found between the groups regarding the goal categories reported first $\left(x^{2} 7=14.73 ; p<.05\right)$. In Table 2, the descriptive data of the two groups' answers are displayed.
The category "Professional Goals" grouped the answers of the participants who indicated objectives related to the participant's professional life, such as a wage increase, a promotion, among other answers with similar contents. This category corresponded to $50.9 \%$ of the college students' answers and $32.4 \%$ of the slum dwellers' answers, representing

Table 2

Accomplishment Goal of Participants (First Answer)

\begin{tabular}{|c|c|c|c|c|c|c|}
\hline \multirow{2}{*}{ Categories } & \multicolumn{3}{|r|}{ Slum Dwellers } & \multicolumn{3}{|r|}{ College Students } \\
\hline & $N$ & $\%$ & Examples & $N$ & $\%$ & Examples \\
\hline Does not know & 12 & $17.6 \%$ & - & 3 & $5.5 \%$ & - \\
\hline Professional Goal & 22 & $32.4 \%$ & "I want to get a good job" & 28 & $50.9 \%$ & "Work on board in another state" \\
\hline Academic Goal & 16 & $23.5 \%$ & "I hope to get a college degree" & 6 & $10.9 \%$ & “Get my master's" \\
\hline Material/Financial Purchases & 5 & $7.4 \%$ & "Have my own house" & 4 & $7.3 \%$ & "Be able to buy a bigger house" \\
\hline Family Goals & 9 & $13.2 \%$ & "Marry and have children" & 5 & $9.1 \%$ & $\begin{array}{l}\text { "Have my own family, with a } \\
\text { husband and children" }\end{array}$ \\
\hline Social Goals (to help other people) & 1 & $1.5 \%$ & "Do some social project" & 5 & $9.1 \%$ & $\begin{array}{l}\text { "I want to continue doing good and } \\
\text { cooperate with humanity" }\end{array}$ \\
\hline $\begin{array}{l}\text { Social goals (broaden relations and } \\
\text { knowledge) }\end{array}$ & 0 & $0 \%$ & & 1 & $1.8 \%$ & $\begin{array}{l}\text { "Travel around the world and get to } \\
\text { know new people" }\end{array}$ \\
\hline Self-accomplishment & 3 & $4.4 \%$ & "Achieve all of my objectives" & 3 & $5.5 \%$ & $\begin{array}{c}\text { "I hope to be very successful in all } \\
\text { areas of my life" }\end{array}$ \\
\hline Total & 68 & $100 \%$ & & 55 & $100 \%$ & \\
\hline
\end{tabular}

the strongest category in both groups. Next, the category "Academic Goals" grouped answers related to the participant's academic education, corresponding to $10.9 \%$ of the college students and $23.5 \%$ of the young slum dwellers' answers, and was the second most frequent category among the participants' goals. The third most frequent category was "Family Goals", representing $9.1 \%$ of the college students and $13.2 \%$ of the slum dwellers, followed by the categories "Material/Financial Purchases", "Self-accomplishment" and "Social/help".

When observing the gender effect on the goal categories the participants informed, a no significant association was found $\left(x^{2} 7=9.07 ; p>.05\right)$, not even when combined with the type of group. For the variables: birth order, income groups and age ranges, no significant association was found either.
The same tests were applied to the goals that ranked second in the participants' answers and the data found are described in Table 3.

No significant association was found between the goal categories informed in the second place and the type of group $\left(\mathrm{x}^{2} 7=6.99 ; p>.05\right)$, but some important data should be observed. While the academic and professional goal categories predominated as the primary goals, family goals figures as the strongest categories among the secondary goals. The emotional goals, which were not present among any of the primary goals, were cited as secondary goals.

The third goals the participants mentioned were predominantly family-related, but the association with the type of group (college students or slum dwellers) could not be tested,

Table 3

Accomplishment Goals of Participants (Second Answer)

\begin{tabular}{|c|c|c|c|c|c|c|}
\hline \multirow{2}{*}{ Categories } & \multicolumn{3}{|r|}{ Slum Dwellers } & \multicolumn{3}{|r|}{ College Students } \\
\hline & $N$ & $\%$ & Examples & $N$ & $\%$ & Examples \\
\hline Does not know & 1 & $4.2 \%$ & - & 0 & $0 \%$ & - \\
\hline Professional Goal & 5 & $20.8 \%$ & "Get a job that pays well" & 11 & $36.7 \%$ & “Open my own office” \\
\hline Academic Goal & 1 & $4.2 \%$ & "Go to college" & 1 & $3.3 \%$ & "Be admitted to a good music school" \\
\hline Material/Financial Purchases & 5 & $20.8 \%$ & "Have a house to live in" & 2 & $6.7 \%$ & "Buy a larger house" \\
\hline Family Goals & 11 & $45.8 \%$ & $\begin{array}{l}\text { "Being able to help my mother } \\
\text { in the future" }\end{array}$ & 12 & $40.0 \%$ & "Get my own family" \\
\hline Emotional Content & 1 & $4.2 \%$ & "Live well, happily" & 1 & $3.3 \%$ & "Be very happy always" \\
\hline $\begin{array}{l}\text { Social Goals (Broadening } \\
\text { Relations and Knowledge) }\end{array}$ & 0 & $0 \%$ & - & 1 & $3.3 \%$ & "Travel a lot" \\
\hline Self-Accomplishment & 0 & $0 \%$ & - & 2 & $6.7 \%$ & "Be successful in everything I do" \\
\hline Total & 24 & $100 \%$ & & 30 & $100 \%$ & \\
\hline
\end{tabular}


as three accomplishment goals were listed in less than 20 cases. For both groups, most answers were concentrated in the family goal category (33\% of young slum dwellers and $46 \%$ of college students). For the college students' third goals, the categories professional goals, academic goals, emotional goals and material/financial purchases were mentioned by one participant each. In the group of slum dwellers, these same categories were mentioned by two, none and one participant, respectively. Only seven participants informed four accomplishment goals. Among these, the answers were divided between two slum dwellers and two college students who expressed family goals. The three other participants were college students and each of them declared, respectively, professional, academic and emotional goals.

\section{Hope of Accomplishment}

After answering the question "What do you consider doing in your life which you consider very important?", the participants were asked to express their hope of achieving their declared goals. This answer, called Hope of Accomplishment, corresponded to the response to the question "Do you think you will be able to do that?". The question was closed, with the following alternative answers: "Yes", "No", "I don't know" or "I don't want to answer".

The participants' answers were distributed among "yes", "I don't know" and "I don't want to answer". In the group of young college students, $89 \%$ answered that they believed they would achieve the intended goal, while $11 \%$ answered "I don't know". In the group of young slum dwellers, 73\% answered "Yes", 24\% "I don't know" and 2.5\% did not want to answer the question. None of the participants declared they did not believe in the accomplishment of their goals, but more youngsters from the slum communities demonstrated uncertainty about that. This difference was statistically significant, with an association between the hope of accomplishment and the group type $\left(x^{2} 2=6.87 ; p<.05\right)$.

After answering the closed question, the participants justified their answer. These justifications were submitted to content analysis and the categories were defined as reported in the Methods section. Like for hope of accomplishment, the young slum dwellers were more uncertain about the accomplishment of their future plans. Motivational answers were predominant among their justifications (36.8\%) (e.g.: "I will manage because I really want that", "I have faith and I believe in God") or I don't know answers (38.2\%). The answers related to ongoing efforts corresponded to $23.5 \%$. On the opposite, most of the college students declare they believe in the accomplishment of their goals because they are already making efforts to achieve them (e.g.: "I will manage because my grades are good and I'm taking a preparatory course" or "I'm already studying to pass that admission test"). These correspond to $47.4 \%$ of all answers. The other categories, motivational and "does not know", scored lower percentages with $29.8 \%$ and $21.1 \%$, respectively. The distribution of the justifications for the accomplishment of their future targets in this group showed a significant difference $\left(x^{2} 3=8.59 ; p<.05\right)$.

The results indicate that professional and academic goals figure among the goals the participants most desire, whether in the college or slum group. This finding, in accordance with the results by Oliveira (2007) and Oliveira and Saldanha (2010) translates the common concern among youngsters in this age group with professional qualification and inclusion in the job market. Nevertheless, the young slum dwellers showed a higher degree of uncertainty on all aspects (Accomplishment Goals, Justifications and Hope of Accomplishment), confirming the initial hypothesis that, in contexts of greater vulnerability, future projects are constructed in view of uncertainty and under the influence of the risks present, favoring distinguished strategies for the participants' life story (Del Giudice \& Belsky, 2011).

Although the young slums dwellers showed a lower score of future goals, they self-declared their motivation to achieve their goals; and, despite the degree of uncertainty some of them demonstrated in their justifications, the significant majority demonstrates their positive belief in the accomplishment of their goals. These results are opposed to the results by Mendonça (1998) in a research among adolescents between 13 and 18 years of age in Rio de Janeiro. Their results identified little concern with the elaboration of future projects, a great need to enjoy life and a focus on the present, avoiding responsibilities and commitments in their thoughts. The youngsters who participated in the study, although they also manifested indecision, are more involved in the elaboration of goals and plans and more confident in the possibility of achieving them.

In addition, similar proportions of concerns with family goals were observed in the two groups, although it was identified through the content analysis that, for the slum dwellers, these relate to their family of origin while, for the college students, the family goals relate to the desire to have their own family and get married. This result is in line with the fact that more of the young slum dwellers contribute to the family income than the college students; despite the fact that they are part of larger families. Besides this difference in meaning, the youngsters in both groups listed family goals with different proportions and positions amidst their other goals. This demonstrates the distinguished life strategies for young people from different social contexts.

\section{Final Considerations}

This study aimed to fill a gap in the literature and achieved its objectives. The intent was to investigate the future perspectives of youngsters in different sociodemographic contexts. In that sense, it responded to the suggestion by Oliveira and Saldanha (2010) for research in the area, but used broader theoretical foundations to understand the phenomenon. The results can further the understanding of young slum dwellers' future projects, because it is the first research that studies this sample from the perspective of Evolutionary Psychology. Discovering how future perspectives and goals are manifested 
in these groups permits the discussion, in social projects or public policy interventions, of contents that affirm greater security and better conditions to accomplish their future goals for these young people. Investments in their professional training and qualification can reduce the uncertainty many of these youngsters still demonstrate with regard to the future.

Thus, further research on the theme is suggested, addressing the future goals of youngsters in different contexts, in view of the role of sociodemographic variables, using larger samples from different cities or different slums in the same city.

\section{References}

Barkow, J. H., Cosmides, L., \& Tooby, J. (Eds.). (1992). The adapted mind: Evolutionary psychology and the generation of culture. New York, NY: Oxford University Press.

BBC. (2009). Estudo estima que violência pode matar 33 mil jovens no Brasil em 7 anos. Retrieved from http://g1.globo. com/Noticias/Brasil/0,,MUL1237285-5598,00-ESTUDO+ ESTIMA+QUE+VIOLENCIA+PODE+MATAR+MIL+JO VENS+NO+BRASIL+EM+ANOS.html

Bell, C. C., \& Jenkins, E. J. (1993). Community violence and children on Chicago's southside. Psychiatry: Interpersonal and Biological Processes, 56(1), 46-54.

Black, A. E., \& Deci, E. L. (2000). The effects of instructors' autonomy support and students' autonomous motivation on learning organic chemistry: A self-determination theory perspective. Science Education, 84(6), 740-756. doi:10.1002/1098-237X(200011)84:6<740::AIDSCE4>3.0.CO;2-3

Carvalho, R. G., Pocinho, M., \& Silva, C. (2010). Comportamento adaptativo e perspectivação do futuro: Algumas evidências nos contextos da educação e da saúde. Psicologia: Reflexão e Crítica, 23(3), 554-561. doi:10.1590/ S0102-79722010000300016

Daly, M., \& Wilson, M. (2005). Carpe diem: Adaptation and devaluing the future. The Quarterly Review of Biology, 80(1), 55-60.

Damon, W. (1995). Greater expectations: Overcoming the culture of indulgence in America's homes and schools. New York, NY: Free Press.

D’Argembeau, A., Stawarczyk, D., Majerus, S., Collete, F., Van der Linden, M., Feyers, D., Maquet, P., \& Salmon, E. (2010). The neural basis of personal goal processing when envisioning future events. Journal of Cognitive Neuroscience, 22(8), 1701-1713. doi:10.1162/jocn.2009.21314

Deci, E. L., Koestner, R., \& Ryan, R. M. (2001). Extrinsic rewards and intrinsic motivation in education: Reconsidered once again. Review of Educational Research, 71(1), 1-27. doi:10.3102/00346543071001001

Deci, E. L., Vallerand, R. J., Pelletier, L. G., \& Ryan, R. M. (1991). Motivation and education: The self-determination perspective. Educational Psychologist, 26(3-4), 325-346. doi:10.1207/s15326985ep2603\&4_6
Del Giudice, M., \& Belsky, J. (2011). The development of life history strategies: Toward a multi-stage theory. In D. M. Buss \& P. H. Hawley (Eds.), The evolution of personality and individual differences (pp. 154-176). New York, NY: Oxford University Press.

Ersner-Hershfield, H., Garton, M. T., Ballard, K., SamanezLarkin, G. R., \& Knutson, B. (2009). Don't stop thinking about tomorrow: Individual differences in future selfcontinuity account for saving. Judgment and Decision Making, 4(4), 280-286.

Ersner-Hershfield, H., Wimmer, G. E., \& Knutson, B. (2009). Saving for the future silf: Neural measures of future self-continuity predict temporal discounting. Social Cognitive and Affective Neuroscience, 4(1), 85-92. doi:10.1093/scan/nsn042

Filak, V. F., \& Sheldon, K. M. (2003). Student psychological need satisfaction and college teacher-course evaluations. Educational Psychology, 23(3), 235-247. doi:10.1080/0144341032000060084

Garbarino, J. (2008). Why are adolescents violent? Ciência \& Saúde Coletiva, 14(2), 533-538. doi:10.1590/S1413-81232009000200021

Garn, A. C., Matthews, M. S., \& Jolly, J. L. (2010). Parental influences on the academic motivation of gifted students: A self-determination theory perspective. Gifted Child Quarterly, 54(4), 263-272. doi:10.1177/0016986210377657

Günther, I. A., \& Günther, H. (1998). Brasílias pobres, Brasílias ricas: Perspectivas de futuro entre adolescentes. Psicologia: Reflexão e Crítica, 11(2), 191-207. doi:10.1590/S0102-79721998000200003

Hill, E. M., Jenkins, J., \& Farmer, L. (2008). Family unpredictability, future discounting, and risk taking. The Journal of Socio-Economics, 37(4), 1381-1396. doi:10.1016/j.socec.2006.12.081

Instituto Brasileiro de Geografia e Estatística. (2008). Armazém de dados: Indicadores sociodemográficos. Retrieved from http://www.pnud.org.br/pdf/Tabela\%20 6.2.22\%20IDH\%20bairro\%2091_00-15_12_03.xls

Jang, L. Y., \& Liu, W. C. (2012). 2 x 2 achievement goals and achievement emotions: A cluster analysis of students' motivation. European Journal of Psychology of Education, 27(1), 59-76. doi:10.1007/s10212-011-0066-5

Leccardi, C. (2005). Para um novo significado do futuro: Mudança social, jovens e tempo. Tempo Social, 17(2), 35-57. doi:10.1590/S0103-20702005000200003

Lee, J. Q., McInerney, D. M., Liem, G. A. D., \& Ortiga, Y. P. (2010). The relationship between future goals and achievement goal orientations: An intrinsicextrinsic motivation perspective. Contemporary Educational Psychology, 35(4), 264-279. doi:10.1016/j.cedpsych.2010.04.004

Lens, W. (1993). La signification motivationnelle de la perspective future. Revue Québécoise de Psychologie, 14(1), 69-83. 
Lorion, R. P., \& Saltzman, W. (1993). Children's exposure to community violence: Following a path from concern to research to action. Psychiatry: Interpersonal and Biological Processes, 56(1), 55-65.

Mendonça, V. M. (1998). Adolescentes urbanos e o mundo atual: Descrição fenomenológica de vivências. (Unpublished master's thesis). Pontifícia Universidade Católica, Campinas, SP.

Natanzon, M., \& Ferguson, M. J. (2012). Goal pursuit is grounded: The link between forward movement and achievement. Journal of Experimental Social Psychology, 48(1), 379-382. doi:10.1016/j.jesp.2011.06.021

Nuttin, J. (1983). Teoria da motivação humana: Da necessidade ao projeto de ação (P. L. Cabra, Trad.). São Paulo, SP: Loyola.

Oliveira, D. C. (2008). Análise de conteúdo temáticocategorial: Uma proposta de sistematização. Revista Enfermagem UERJ, 16(4), 569-76.

Oliveira, I. C. V., \& Saldanha, A. A. W. (2010). Estudo comparativo sobre a perspectiva de futuro dos estudantes de escolas públicas e privadas. Paideia (Ribeirão Preto), 20(45), 47-55. doi:10.1590/S0103-863X2010000100007

Oliveira, M. C. S. L., Pinto, R. G., \& Souza, A. S. (2003). Perspectivas de futuro entre adolescentes: Universidade, trabalho e relacionamentos na transição para a vida adulta. Temas em Psicologia, 11(1), 16-27.

Oliveira, R. S. (2007). Expectativas quanto ao trabalho: Um estudo com jovens que vivem em assentamento rural no município de São Francisco do Pará. Amazônia: Ciência e Desenvolvimento, 2(4), 105-117.

Osofsky, J. D., Wewers, S., Hann, D. M., \& Fick, A. C. (1993). Chronic community violence: What is happening to our children? Psychiatry: Interpersonal and Biological Processes, 56(1), 36-45.

Peetsma, T., \& van der Veen, I. (2011). Relations between the development of future time perspective in three life domains, investment in learning, and academic achievement. Learning and Instruction, 21(3), 481-494. doi:10.1016/j.learninstruc.2010.08.001

Ramos, D. O., \& Victor, T. A. S. (2009). Desenvolvimento e perspectivas de futuro de jovens. In M. L. Seidl-deMoura, D. M. L. F. Mendes, \& L. F. Pessôa, Interação social e desenvolvimento (pp. 207-220). Rio de Janeiro, RJ: Editora CRV.

Ryan, R. M., \& Deci, E. L. (2000). Intrinsic and extrinsic motivations: Classic definitions and new directions. Contemporary Educational Psychology, 25(1), 54-67. doi:10.1006/ceps.1999.1020

Ryan, R. M., \& Niemiec, C. P. (2009). Self-determination theory in schools of education: Can an empirically supported framework also be critical and liberating? Theory and Research in Education, 7(2), 263-272. doi:10.1177/1477878509104331
Ryan, R. M., Stiller, J. D., \& Lynch, J. H. (1994). Representations of relationships to teachers, parents, and friends as predictors of academic motivation and selfesteem. Journal of Early Adolescence, 14(2), 226-249. doi:10.1177/027243169401400207

Ryan, R. M., \& Weinstein, N. (2009). Undermining quality teaching and learning: A self-determination theory perspective on high-stakes testing. Theory and Research in Education, 7(2), 224-233. doi: $10.1177 / 1477878509104327$

Rosa, H. (2003). Social acceleration: Ethical and political consequences of a desynchronized high-speed society. Constellations, 10(1), 3-33. doi:10.1111/1467-8675.00309

Schacter, D. L., \& Addis, D. R. (2009). Remembering the past to imagine the future: A cognitive neuroscience perspective. Militar Psychology, 21(Suppl 1), S108S122. doi:10.1080/08995600802554748

Schmitt, R. E. (2010). Teoria da perspectiva de tempo futuro: Aplicações preliminares e reflexões voltadas à pesquisa no ensino superior. Revista Educação por Escrito, 1(1), 5-16.

Tabachnick, S. E., Miller, R. B., \& Relyea, G. E. (2008). The relationships among students' future-oriented goals and subgoals, perceived task instrumentality, and task-oriented self-regulation strategies in an academic environment. Journal of Educational Psychology, 100(3), 629-642. doi:10.1037/0022-0663.100.3.629

Wang, F. (2008). Motivation and English achievement: An exploratory and confirmatory factor analysis of a new measure for Chinese students of English learning. North American Journal of Psychology, 10(3), 633-646.

Williams, G. G. (1957). Pleiotropy, natural selection, and the evolution of senescence. Evolution, 11, 398-411.

Dandara de Oliveira Ramos is a Ph.D. candidate in Collective Health of the Institute of Social Medicine at the Universidade do Estado do Rio de Janeiro.

Maria Lucia Seidl-de-Moura is a Full Professor at the Psychology Institute of Universidade do Estado do Rio de Janeiro.

Luciana Fontes Pessôa is an Assistant Professor at the Pontifícia Universidade Católica do Rio de Janeiro.

Received: May $16^{\text {th }} 2012$

$1^{\text {st }}$ Revision: May $15^{\text {th }} 2013$

Approved: Jun. $21^{\text {st }} 2013$

How to cite this article:

Ramos, D. O., Seidl-de-Moura, M. L., \& Pessôa, L. F. (2013). Achievement goals of youngsters in Rio de Janeiro in different contexts. Paidéia (Ribeirão Preto), 23(56), 321-328. doi:10.1590/1982-43272356201306 